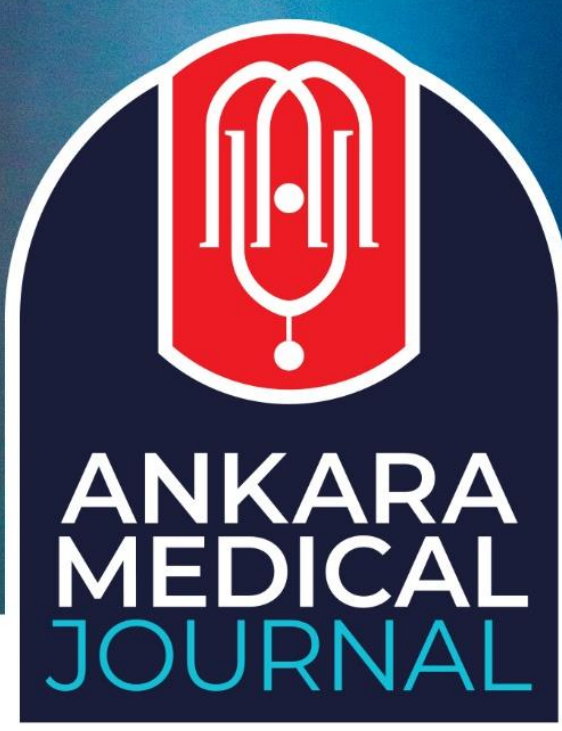

Case Report

Ankara Med J, 2020;(4): 1094-1098 // 1010.5505/amj.2020.69335

\title{
VARICELLA ZOSTER CO-INFECTION IN A PATIENT WITH COVID-19
}

\section{COVID-19'LU BİR HASTADA VARİSELLA ZOSTER KO- ENFEKSIYONU}

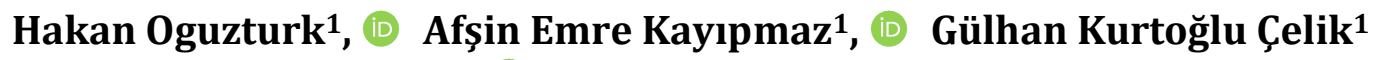 (iD) Semih Korkut ${ }^{2}$ \\ ${ }^{1}$ Ankara City Hospital, Ankara \\ 2Turkish Republic, Ministry of Health, Ankara}

Yazışma Adresi / Correspondence:

Doç. Dr. Gülhan Kurtoğlu Çelik (e-mail: kurtoglugulhan@yahoo.com)

Geliş Tarihi (Submitted): 14.10.2020 // Kabul Tarihi (Accepted): 17.11.2020

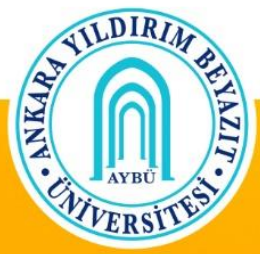

Ankara YIldırım Beyazıt University Faculty of Medicine

Department of Family Medicine 


\title{
Öz
}

COVID-19 Hastalığı, asemptomatik enfeksiyondan kritik hastalığa kadar geniş bir klinik yelpazeye sahiptir, az sayıda COVID-19 hastası ölümle sonuçlanabilecek ciddi hastalıklar yaşar. Literatürde COVID-19 hastalığında kutanöz lezyonlarla ilgili daha az bilgi mevcuttur. 42 yaşında, bilinen hastalığı olmayan erkek hasta, 3 gün önce başlayan ateș, kuru öksürük, halsizlik, kızarıklık ve baș ağrısı şikayetlerinden sonra acil servisimize geldi. Bu yazıda, COVID-19 enfeksiyonunun zona zoster gibi diğer hastalıklarda da görülebileceği konusunda farkındalık yaratmayı amaçladık.

Anahtar Kelimeler: COVID-19, Varisella Zoster, döküntü.

\begin{abstract}
COVID-19 Disease has a wide clinical spectrum from asymptomatic infection to critically ill, a small number of COVID-19 patients experience a severe illness that can result in death. Less information is available in the literature regarding cutaneous lesions in COVID-19 disease. A 42-year-old male patient with no known disease came to our emergency department after fever, dry cough, weakness, rashes, and headache complaints that started 3 days ago. In this article, we aimed to report this case to raise awareness that COVID-19 infection can be accompanied by other diseases such as zona zoster.

Keywords: COVID-19, Varicella Zoster, rash.
\end{abstract}




\section{Introduction}

Varicella zoster virus (VZV) is a double-stranded DNA virus that belongs to the alpha subgroup of the Herpesviridae family. VZV creates two different clinical pictures. These are juvenile chickenpox and shingles disease caused by reactivation of latent VZV. ${ }^{1}$ The virus becomes latent in the cerebral or posterior root ganglia after the primary infection. It is called zona zoster, which results in this latent virus becoming active with various factors, reaching the skin in the axon of the sensory nerves, and forming a rash. ${ }^{2,3}$

The most common symptom of the disease is pain accompanied by itching. During the disease, many complications can develop from aseptic meningitis to transverse myelitis, vision problems, and deafness. The diagnosis of shingles is made with the presence of classical prodromal pain-burning and shingles rashes.

Having more information about COVID-19 disease, which continues to be a global health problem all over the world, guides us in the fight against it.

COVID-19 patients can be asymptomatic, or they can apply to the hospital with signs and symptoms such as cough, sore throat, fever, shortness of breath, diarrhea, loss of taste, and smell. ${ }^{1,4}$ It has been observed that various parameters are related to the course of the disease. Compared to Europe $(\% 6,57)$ and America $(\% 5,7)$ COVID-19 Infection in Turkey $(\% 2,71)$ has a lower mortality rate. ${ }^{5}$

Less information is available in the literature regarding cutaneous lesions in COVID-19 disease. As can be seen in our case, COVID-19 disease can also occur with rashes. In this article, we aimed to report this case to raise awareness that COVID-19 infection can be seen with other diseases such as zona zoster.

\section{Case}

A 42-year-old male patient with no known disease came to our emergency department after fever, dry cough, weakness, headache complaints that started 3 days ago. The general condition of the patient was good. He was conscious, orientated, and cooperative. The vital signs were measured as fever $36.4{ }^{\circ} \mathrm{C}$, pulse rate 78 / min, respiratory rate 28 / $\mathrm{min}$, blood pressure $110 / 75 \mathrm{mmHg}$.

On physical examination, the patient had itchy lesions in the right thorax and back. The patient said that two days ago, a rash on the right chest and then itchy vesicular lesions appeared. (Figure1) He also stated that complaints of weakness and pain were added. 
Laboratory examinations revealed: hemoglobin 14.6 g / dL (13.5-18 g / dL), white blood cell count 6.580 / mm3 (neutrophil 52\%, lymphocyte 21\%, monocyte 10\%), platelet count 224,000 / mm3 (150-450,000/ mm³), C-reactive protein (CRP): $2.48 \mathrm{mg} / \mathrm{L}$ (0-8 mg / L). Other biochemical tests were within normal limits. Serum VZV IgM serology of the patient was positive. The patient's SARS-CoV2 test was positive in the nasopharyngeal swab. Antipruritic, antihistamine drugs, and acyclovir treatment were started on the patient. Treatment for COVID-19 was not started, except for isolation. Recovery was achieved without complications.
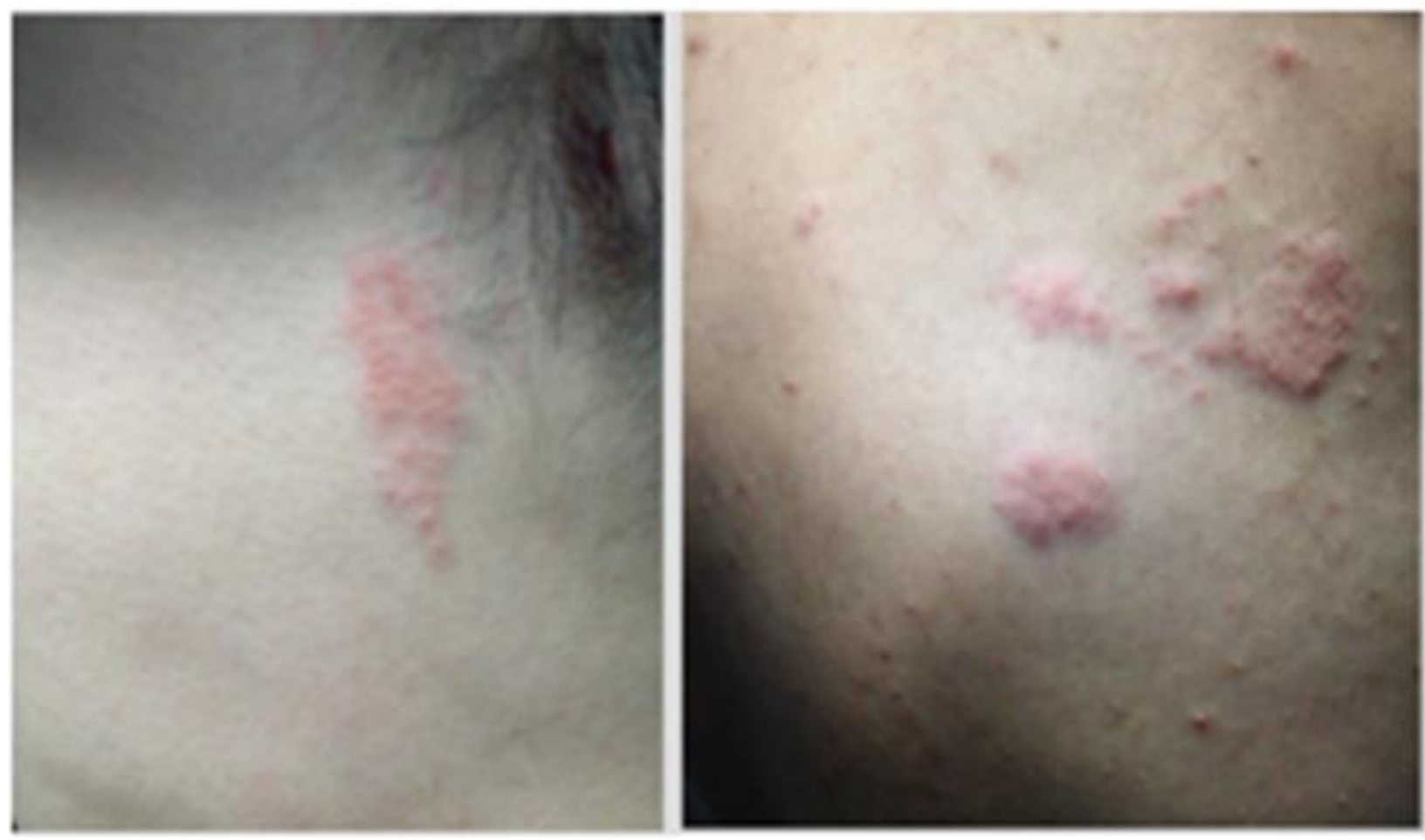

Figure 1. Characteristic lesions of shingles on thorax

\section{Discussion}

Conditions that weaken the cellular immune system such as AIDS, bone marrow-organ transplantation, psychological stress, cancer, trauma, old age, heavy workload, and immunosuppressive drug use can be the trigger in shingles reactivation. ${ }^{1}$ There was no history of psychological stress, immunodeficiency, malignancy, and immunosuppressive drug use in this patient. However, the SARS-Cov2 test was positive. 
Activation of the recognition receptors presented on the surface of immune cells against coronaviruses, which are factors of COVID-19 disease, stimulates the host's response. Following this, in addition to immune activation, a cytokine storm develops in a short time and activates the inflammatory response. ${ }^{6}$

As a result, the progression of the hyper-inflammatory condition causes immune cell dysfunction. These conditions are also suitable conditions for the activation of Herpes zoster. We believe that the shingles have developed with this mechanism in our patient. Our case emphasizes the association of COVID-19 with shingles. During case management, COVID-19 awareness should also occur in patients with skin complaints accompanied by the highest infection control measures. 


\section{References}

1. Arvin AM. Varicella-zoster virus. Clinical Microbiology Reviews. 1996;9(3):361-81 (doi:10.1128/cmr.9.3.361)

2. Elsaie ML, Youssef EA, Nada HA. Herpes zoster might be an indicator for latent COVID 19 infection. Dermatol Ther. 2020;33(4):e13666 (doi:10.1111/dth.13666).

3. Saati A, Al-Husayni F, Malibari AA, Bogari AA, Alharbi M. Herpes Zoster Co-Infection in an Immunocompetent Patient With COVID-19. Cureus. 2020;12(7):e8998 (doi:10.7759/cureus.8998).

4. Oguzturk H, Kayipmaz AE. Coronaviruses. In: Oguzturk H, ed. COVID-19 and Emergency Medicine. Ankara: Turkish Clinics; 2020:1-4.

5. Dağcioğlu BF, Keskin A. Data Comparison of Turkey, Europe, and USA During COVID-19 Process: A Cross-Sectional Study. Ankara Medical Journal. 2020;20(2):360-9 (doi:10.5505/amj.2020.02328).

6. Rittirsch D, Flierl MA, Ward PA. Harmful molecular mechanisms in sepsis. Nat Rev Immunol. 2008;8(10):776-87 (doi:10.1038/nri2402). 